\title{
Subjective Symptom Increase Among Dry-Cleaning Workers Exposed to Tetrachloroethylene Vapor
}

\author{
Shi-Xiong CAI ${ }^{1)}$, Mei-Yuan HUANG ${ }^{1)}$, Zhen CHEN'), Yu-Tang LIU'), \\ Chui JIN"), Takao WATANABE ${ }^{2)}$, Haruo NAKATSUKA ${ }^{3)}$, \\ Kazunori SEIJI $^{3,4)}$, Osamu INOUE ${ }^{3,4)}$ and Masayuki IKEDA ${ }^{5)}$ \\ 1) Institute of Occupational Medicine, Chinese Academy of \\ Preventive Medicine, Beijing, China \\ 2) Miyagi University of Education, Sendai 980, Japan \\ 3) Department of Environmental Sciences, Tohoku University School of \\ Medicine, Sendai 980, Japan \\ 4) Tohoku Rosai Hospital, Sendai 980, Japan \\ 5) Department of Public Health, Kyoto University Faculty of \\ Medicine, Kyoto 606-01, Japan
}

(Received December 25, 1990 and in revised form June 17, 1991)

\begin{abstract}
Subjective symptoms, hematology, serum biochemistry and other clinical signs were investigated in 56 dry-cleaning workers exposed to tetrachloroethylene at $20 \mathrm{ppm}$ (as a geometric mean of 8 -hr time-weighted average), and the results were compared with the findings in 69 non-exposed controls from the same factories. There were exposure-related increases in the prevalence of subjective symptoms during the work as well as in the past 3 month period, whereas there was no significant changes in hematology. Effects of the exposure on liver and kidney functions were also negative as judged by emission enzyme activities, BUN and creatinine in the serum.
\end{abstract}

Key words: Hematology-Liver function-Kidney function-Occupational exposure-Subjective symptoms-Tetrachloroethylene

\section{INTRODUCTION}

Tetrachloroethylene (TETRA, or perchloroethylene) has been used in industries primarily as a degreaser, especially for dry cleaning of cloth. Despite the fact that this chemical is carcinogenic at least to experimental animals ${ }^{1)}$ and might have reproductive toxicity, ${ }^{2)}$ cases of environmental pollution has also being reported $^{3-6)}$ because of its popular use in close contact with general population. The reports on the possible health effects after chronic occupational exposure to

Request for offprints should be addressed to: Prof. M. Ikeda, Department of Public Health, Kyoto University Faculty of Medicine, Kyoto 606-01, Japan 
this widely used solvent are however relatively scarce in literature. ${ }^{7)}$ A factory survey was conducted in this study to examine if there is any positive evidence of effects on the central nervous system (CNS) and liver functions among those who were occupationally exposed to this solvent as dry-cleaning workers.

The relation of TETRA vapor exposure with urinary excretion of metabolites has been described in a separate paper. ${ }^{8)}$ The possible effects on sister chromatid exchange in peripheral lymphocytes of the workers were also studied. ${ }^{9)}$

\section{Materials ANd Methods}

\section{Workers studied}

The factory survey (Table 1) was conducted in the second half of a working week, although this consideration for the maximum internal exposure ${ }^{10}$ may not be necessary because TETRA has a long biological half-time of over one hundred hours. ${ }^{11)}$ In total, 56 TETRA-exposed workers were examined, who had been serving in 3 dry-dcleaning workshops for several years (Table 1). Because TETRA exposure intensity was almost the same in the 3 dry-cleaning workshops, 56 workers ( 29 men and 27 women) as a whole were pooled to make up a TETRA-exposed group. The nonexposed control workers of similar ages (32 men and 37 women; Table 1) were recruited from the same factories but in workshops with no solvent exposure.

Table 1. Age and service duration of the exposed workers and the non-exposed controls

\begin{tabular}{|c|c|c|c|c|c|c|}
\hline \multirow{2}{*}{ Sex } & \multicolumn{3}{|c|}{ Exposed } & \multicolumn{3}{|c|}{ Non-exposed } \\
\hline & No. & Age & Service & No. & Age & Service \\
\hline Men & 29 & $33.8(17-55)$ & $39.3(2-120)$ & 32 & $37.9(22-65)$ & $72.5(1-436)$ \\
\hline Women & 27 & $36.4(18-51)$ & $33.1(1-83)$ & 37 & $31.5(19-52)$ & $42.8(1-198)$ \\
\hline Total & 56 & $35.1(17-55)$ & $36.3(1-120)$ & 69 & $34.5(19-65)$ & $56.6(1-436)$ \\
\hline
\end{tabular}

Except for number of subjects (No.), values in the table are arithmetic mean (minimum-maximum) of the ages (in years) and service duration (in months).

\section{Exposure measurements}

The time-weighted average exposure intensity was monitored by means of diffusive sampling with carbon cloth KF-1500 (Toyobo Co., Osaka, Japan) as absorbent. ${ }^{12,13)}$

\section{Subjective symptom survey}

The subjective symptom questionnaire set employed was originally designed by Inoue $^{14)}$ in Japanese, and subsequently modified and translated into both English and Chinese by the present study group. ${ }^{15,16)}$ The survey was conducted in a clinical interview by a doctor, asking all the questions in the set verbally. There are 12 questions in Part 1 (i.e., the symptoms during work), and 57 for men or 
59 for women in Part 2 (i.e., those in past 3 month period).

The rate of subjective symptom prevalence is defined as

Number of affirmative answers

(Number of subjects) $\times($ Number of questions in the Part $)$.

\section{Clinical examination}

The clinical examination included palpation, auscultation, skin observation and tendon reflex examination, with foci on neurology and possible liver damage.

\section{Evaluation of hematology and serum biochemistry}

Hematology and serum biochemistry were conducted by conventional methods under strict quality control. In evaluating the results, log-normal distribution was assumed for enzymic parameters taking the clinically established normal range as a $4 \times$ GSD (geometric standard deviation) range, whereas normal distribution was considered for non-enzymic ones taking the normal range as $4 \times$ ASD (arithmetic standard deviation) range. Thus the lower and upper limits of the borderline range (i.e., the line between the borderline and abnormal values) were set at GM $/(\mathrm{GSD})^{3}$ and $\mathrm{GM} \times(\mathrm{GSD})^{3}$ respectively for the formers, and at $\mathrm{AM}-4 \mathrm{ASD}$ and $\mathrm{AM}+4 \mathrm{ASD}$ respectively for the latters (except for WBC counts), where GM and AM are geometric and arithmetic means. The values thus set (see Tables 6 and 7 for examples) agree well with the evaluation in clinical practice. In the case of WBC counts, 3000 cells $/ \mathrm{mm}^{3}$ was selected as the lower borderline limit based on the clinical experience. When ASAT and ALAT, or ALP and LAP were evaluated in pair, the case was classified as normal when both enzyme activities (i.e., ASAT and ALAT, for example) stayed in normal ranges, and as abnormal when one of the two parameters was in the borderline or abnormal range and the other was in the abnormal range. Other cases were classified as borderline.

\section{Statistical analysis}

The difference in prevalence between the groups were examined by chi-square test.

\section{RESULTS}

Characteristics of the exposed and the controls, and the exposure

The age and service duration of the exposed and non-exposed subjects are summarized in Teble 1. Ages were comparable between two sexes and also between the exposed and the non-exposed. Service duration was also essentially the same between the two sexes. Although the mean service duration was longer in the exposed than in the non-exposed, no further consideration was made for the possible diffierence because of wide ranges in the distributions. The timeweighted average intensity of exposure was such that the concentration was close 
to $100 \mathrm{ppm}$ in a few cases, but mostly much lower than that, so that the GM was about $20 \mathrm{ppm}$ in both sexes and therefore in the combination of the two sexes (Table 2).

Increase in subjective symptom prevalence after TETRA exposure

Subjective symptom prevalence (for definition, see Materials and Methods) was calculated for the comparison between the TETRA-exposed workers and the controls. It was found that there was an increase $(p<0.001)$ in the rate both in Part 1 and Part 2 of the questionnaires among the exposed regardless of sexes (and therefore the two sexes combined) as compared with the rates among the corresponding controls (Table 3 ). Further break-down of the exposed group into 3 dose (i.e., $<10,10-20$, and $>20 \mathrm{ppm}$ ) subgroups of a comparable size (5 to 12 men or women, or 11-23 subjects of either sex) and comparison of the rates, however, failed to detect any note-worthy dose-response relationship in Part 1 symptoms (Table 3). In Part 2 symptoms, there was an increase in the 10-20 ppm subgroup as well as in the over $20 \mathrm{ppm}$ subgroup in some cases, but the rates in the over $20 \mathrm{ppm}$ subgroup were not significantly higher than the rates in the $10-20 \mathrm{ppm}$ subgroup.

To identify the symptoms with a significant increase after exposure, the prevalence of each symptom in Part 1 and 2 was compared between the exposed and the non-exposed controls. Symptoms with a significant increase are listed in Table 4 (those during work, i.e., Part 1) and Table 5 (those in past 3 month period, i.e., Part 2), respectively. The Part 1 symptoms thus listed included several CNS-related symptoms such as dizziness, floating sensation, drunken feeling and heavy feeling in head among the exposed group. Headache also showed an increase but only with bare significance. Nasal irritation and sore throat may reflect the local effects of TETRA. The analyses of Part 2 symptoms (Table 4) revealed that some complaints such as heavy feeling in head and drunken feeling are essentilally reproducible when asked about its presence in past 3 months period. In addition, some long-term effects such as forgetfulness, rough skin and frequent cough are also complained. Loss in hearing capacity (as a subjective judgement with no objective measurement) might be associated with

Table 2. Exposure to TETRA in three workshops

\begin{tabular}{|c|c|c|c|c|c|c|c|c|c|}
\hline \multirow{3}{*}{ Workshop } & \multicolumn{9}{|c|}{ TETRA (ppm) } \\
\hline & \multicolumn{3}{|c|}{ Men } & \multicolumn{3}{|c|}{ Women } & \multicolumn{3}{|c|}{ Total } \\
\hline & No. & GM & Min. -Max. & No. & GM & Min. -Max. & No. & GM & Min. -Max. \\
\hline 1 & 11 & 23.4 & 7. $1-92.8$ & 10 & 21.7 & 7. $7-75.9$ & 21 & 22.6 & 7. $1-92.8$ \\
\hline 2 & 9 & 27.3 & $11.7-60.7$ & 12 & 15. 5 & 4. 5-51. 5 & 21 & 19. 8 & 4. $5-60.7$ \\
\hline 3 & 9 & 12. 5 & $3.8-51.7$ & 5 & 25.1 & 10. $7-94.4$ & 14 & 16.0 & 3. $8-94.4$ \\
\hline Total & 29 & 21.2 & 3. $8-92.8$ & 27 & 19.6 & 4. $5-94.4$ & 56 & 19. 9 & $3.8-94.4$ \\
\hline
\end{tabular}

Except for number of subjects (No.), values in the table are geometric mean (minimum-maximum) of the concentrations. 


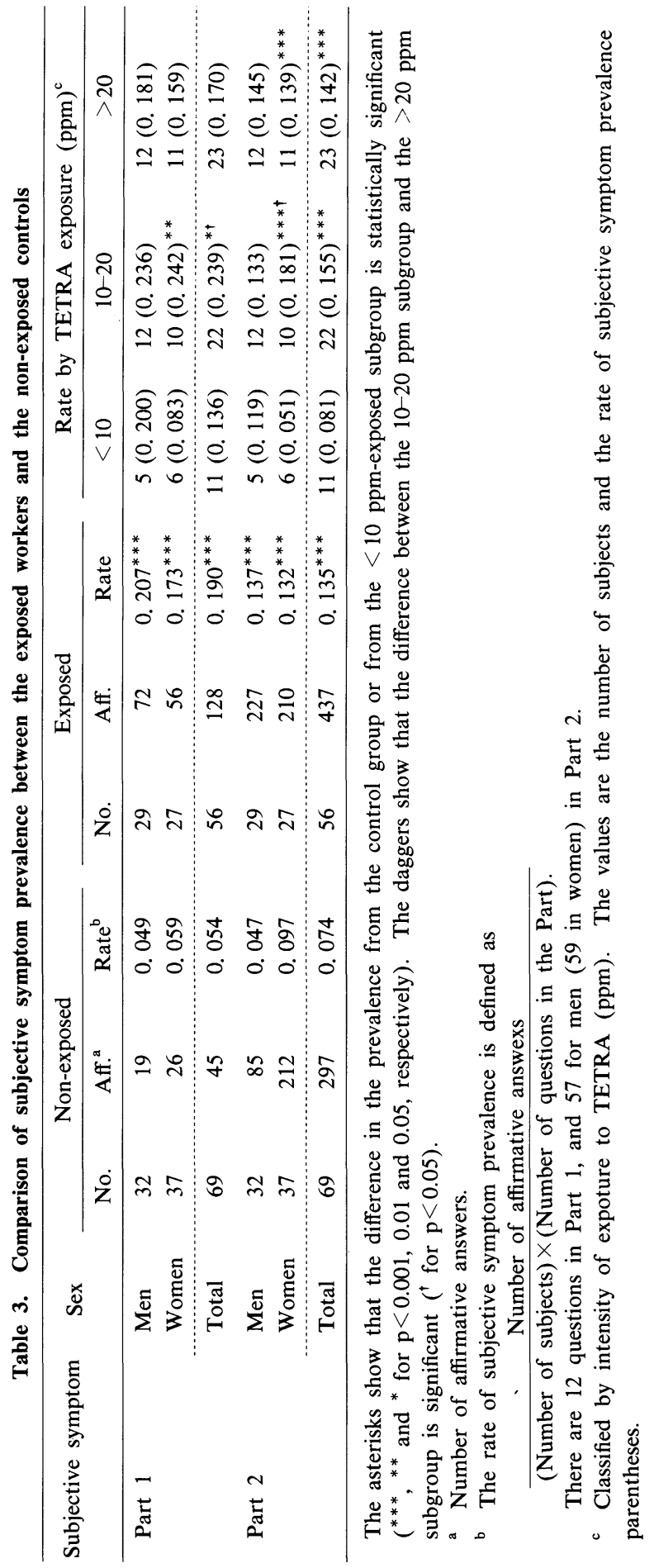


rather noisy working environments.

Serum biochemistry, hematology, and clinical signs

Serum biochemistry results (Table 6) showed that there was no exposurerelated increase in the prevalence of borderline or abnormal cases in ASAT/ ALAT, $\gamma$-GTP, ALP/LAP nor total bilirubin, suggesting that the exposure to TETRA did not result in liver function disturbances. Such was also the case for kidney functions as examined by BUN and creatinine levels.

Hematological changes were also negative as examined in terms of RBC counts, hemoglobin concentration, hematocrit value and $\mathrm{WBC}$ counts. The results of hemoglobin concentration and WBC counts analyses are summarized in Table 7 as examples in hematology studies. Clinical examinations including auscultation, abdominal palpation and tendon reflex examination were also not informative; examples are shown in Table 8.

\section{Discussion}

The present study on possible neurotoxicity, hematotoxicity, hepato-renal toxicity and local irritation effects of TETRA in chronically exposed workers showed that symptoms related to the CNS effects and local effects on mucous membrane and skin are increased in the workers exposed to TETRA. The CNS-related symptoms during work (i.e., Part 1 symptoms) included dizziness, floating sensation and drunken feeling, and possibly headache also (Table 4). Similar symptoms as well as forgetfulness, rough skin and frequent cough were complained off

Table 4. Prevalence of subjective symptoms during work: Comparison of the exposed workers with the non-exposed controls

\begin{tabular}{|c|c|c|c|}
\hline & \multirow{2}{*}{ Symptom $^{\mathrm{a}}$} & Exposed & \multirow{2}{*}{$\begin{array}{c}\text { Non-exposed } \\
\text { No. }(\%)\end{array}$} \\
\hline & & No. $(\%)$ & \\
\hline 3. & Nasal irritation & $16(28.6)^{* *}$ & $5(7.2)$ \\
\hline 4. & Unusual smell & $11(19.6)^{* * *}$ & $0(0.0)$ \\
\hline 5. & Sore throat & $11(19.6)$ & $6(8.7)$ \\
\hline 7. & Face flashing & $5(8.9)^{*}$ & $0(0.0)$ \\
\hline 8. & Dizziness & $25(44.6)^{* * *}$ & $8(11.6)$ \\
\hline 9. & Floating sensation & $13(23.2)^{* *}$ & $4(5.8)$ \\
\hline 10. & Drunken feeling & $10(17.9)^{* * *}$ & $0(0.0)$ \\
\hline 11. & Heavy feeling in head & $11(19.6)^{* * *}$ & $1(1.4)$ \\
\hline 12. & Headache & $13(23.2)$ & $8(11.6)$ \\
\hline
\end{tabular}

The number of subjects studied is 56 in the TETRA-exposed group, and 69 in the control group. The asterisks show that the difference in the prevalence from the control group is statistically significant $\left({ }^{* * *},{ }^{* *}\right.$ and ${ }^{*}$ indicates $\mathrm{p}<0.001,0.01$, and 0.05 , respectively). Only symptoms with significant difference in the prevalence are described; sore throat and headache are with bare significance $(0.10<p<0.05)$ and are shown for references.

a Part 1 symptoms during work in the questionnaire set. 
Table 5. Prevalence of subjective symptoms in recent 3 months: Comparison of the exposed workers with the non-exposed controls

\begin{tabular}{|c|c|c|c|}
\hline & \multirow{2}{*}{ Symptom $^{a}$} & \multirow{2}{*}{$\begin{array}{l}\text { Exposed } \\
\text { No. }(\%)\end{array}$} & \multirow{2}{*}{$\begin{array}{c}\text { Non-exposed } \\
\text { No. }(\%)\end{array}$} \\
\hline & & & \\
\hline 1. & Heavy feeling in head & $9(16.1)^{* *}$ & $1(1.4)$ \\
\hline 11. & Drunken feeling & $6(10.7)^{*}$ & $0(0.0)$ \\
\hline 13. & Forgetfulness & $22(39.3)^{* *}$ & $10(14.5)$ \\
\hline 18. & Fainting after sudden standing up & $20(35.7)^{* *}$ & $10(14.5)$ \\
\hline 23. & Dullness in extremities & $15(26.8)^{*}$ & $8(11.6)$ \\
\hline 24. & Poor appetite & $15(26.8)^{* *}$ & $4(5.8)$ \\
\hline 32. & Changes in perspiration pattern & $10(17.9)^{* *}$ & $1(1.4)$ \\
\hline 38. & Loss in hearing capacity & $11(19.6)^{* * *}$ & $1(1.4)$ \\
\hline 43. & Joint pain & $8(14.3)^{* *}$ & $0(0.0)$ \\
\hline 50. & Rough skin & $8(14.3)^{* *}$ & $0(0.0)$ \\
\hline 52. & Frequent cough & $8(14.3)^{*}$ & $2(2.9)$ \\
\hline 59. & Frequent flatus & $12(21.4)^{* * *}$ & $1(1.4)$ \\
\hline
\end{tabular}

The asterisks show that the difference in the prevalence from the control group is statistically significant $\left({ }^{* * *},{ }^{* *}\right.$ and ${ }^{*}$ indicates $\mathrm{p}<0.001,0.01$, and 0.05 , respectively).

a Part 2 symptoms in the post 3 months; only those with significant difference are show.

Table 6. Abnormal liver and kindney function prevalence : Comparison between the exposed workers and the non-exposed controls

\begin{tabular}{|c|c|c|c|c|c|c|}
\hline \multirow{2}{*}{$\begin{array}{l}\text { Serum } \\
\text { biochemistry } \\
\text { item }\end{array}$} & \multirow{2}{*}{ y [ [EC No.] } & \multirow{2}{*}{ Unit } & \multirow{2}{*}{$\begin{array}{l}\text { Normal } \\
\text { range }\end{array}$} & \multirow{2}{*}{$\begin{array}{l}\text { Upper } \\
\text { border } \\
\text { line }\end{array}$} & Exposed & \multirow{2}{*}{$\begin{array}{c}\text { Non-exposed } \\
\text { Abn./Bor./Nor. }\end{array}$} \\
\hline & & & & & Abn./Bor./Nor. ${ }^{a}$ & \\
\hline ASAT & {$[2.6 .1 .1]$.} & KU & $8-23$ & 29.9 & \multirow[b]{2}{*}{$2 / 2 / 52$} & \multirow[b]{2}{*}{$1 / 3 / 61$} \\
\hline ALAT & {$[2.6 .1 .2]$.} & $\mathrm{KU}$ & $3-20$ & 32.1 & & \\
\hline$\gamma$-GTP & {$[2.3 .2 .1]$.} & $\mathrm{IU} / 1$ & $2-39$ & 62.5 & $0 / 1 / 55$ & $0 / 0 / 65$ \\
\hline ALP & {$[3.1 .3 .1]$.} & KAU & 2. $6-10.0$ & 14. 0 & \multirow[b]{2}{*}{$0 / 8 / 48$} & \multirow[b]{2}{*}{$0 / 6 / 59$} \\
\hline LAR & {$[3,4,1.1]$.} & GRU & $100-170$ & 194. 1 & & \\
\hline \multicolumn{2}{|c|}{ Total bilirubin $\quad n$} & $\mathrm{mg} / 100 \mathrm{ml}$ & $0.3-1.1$ & 1.5 & $1 / 1 / 54$ & $1 / 4 / 60$ \\
\hline BUN & & $\mathrm{ng} / 100 \mathrm{ml}$ & 9-20 & 25.5 & $0 / 2 / 54$ & $0 / 7 / 58$ \\
\hline Creatinine & & $\mathrm{mg} / 100 \mathrm{ml}$ & $0.6-1.2$ & 1.5 & $0 / 0 / 56$ & $0 / 1 / 64$ \\
\hline
\end{tabular}

The number of subjects examined is 56 (29 men and 27 women) in the exposed group and 65 (30 men and 35 women) in the control group. The difference from the number shown in Table 1 is due to inavailability of blood samples. There was no $(p>0.10)$ significant difference in the prevalence between the exposed and the controls.

${ }^{\text {a }}$ Number of cases with an abnormal value/borderline value/normal value in the item studied. For definition of abnormal and borderline values, see MATERIALS AND METHODS section. ASAT and ALAT, and ALP and LAP were evaluated in pair. For details or evaluation procedure, see Materials and Methods. 
Table 7. Abnormal hematology prevalence : Comparison between the exposed workers and the non-exposed controls

\begin{tabular}{|c|c|c|c|c|c|c|}
\hline \multirow{2}{*}{$\begin{array}{c}\text { Hematoloay } \\
\text { item }\end{array}$} & \multirow{2}{*}{ Unit } & \multirow{2}{*}{ Sex } & \multirow{2}{*}{$\begin{array}{l}\text { Normal } \\
\text { range }\end{array}$} & \multirow{2}{*}{$\begin{array}{l}\text { Lower } \\
\text { border } \\
\text { line }\end{array}$} & Exposed & Non-exposed \\
\hline & & & & & Abn./Bor./Nor. ${ }^{a}$ & Abn./Bor./Nor. \\
\hline \multirow{2}{*}{$\begin{array}{l}\text { Hemoglobin } \\
\text { consentration }\end{array}$} & \multirow{2}{*}{$\mathrm{g} / 100 \mathrm{ml}$} & Men & $13.7-17.4$ & 11.9 & \multirow[b]{2}{*}{$0 / 5 / 51$} & \multirow[b]{2}{*}{$1 / 7 / 57$} \\
\hline & & Women & $11.3-14.5$ & 9.5 & & \\
\hline \multirow[t]{2}{*}{ WBC counts } & \multirow[t]{2}{*}{$\mathrm{x} 10^{3} / \mathrm{mm}^{3}$} & Men & 4. $1-6.1$ & 3.0 & \multirow[b]{2}{*}{$0 / 1 / 55$} & \multirow[b]{2}{*}{$0 / 1 / 65$} \\
\hline & & Women & $3.9-6.3$ & 3. 0 & & \\
\hline
\end{tabular}

The number of subjects examined is 56 (29 men and 27 women) in the exposed group and 65 (30 men and 35 women) in the non-exposed control ggroup. The difference from the number shown in Table 1 is due to inavailability of blood samples. There was no significant $(p>0.10)$ difference in the prevalence between the exposed workers and the non-exposed controls.

${ }^{\text {a }}$ Number of cases with an abnormal value/ borderline value/ normal value in the item studied. For definition of abnormal and borderline values, and for details of evaluation procedure, see MATERIALS AND METHODS.

Table 8. Clinical signs : Comparison between the exposed workers and the non-exposed controls

\begin{tabular}{llcccc}
\multicolumn{1}{c}{ Symptom $^{\mathrm{a}}$} & \multicolumn{2}{c}{ Exposed } & & \multicolumn{2}{c}{ Non-exposed } \\
\cline { 2 - 3 } \cline { 5 - 6 } & \multicolumn{2}{c}{ NO. $^{\mathrm{a}}(\%)$} & & No. (\%) \\
\hline Abnormal ankle jerk reflex & 2 & $(3.6)$ & & 6 & $(8.7)$ \\
Liver enlargement & 0 & $(0.0)$ & & 2 & $(2.9)$ \\
Tenderness of liver & 0 & $(0.0)$ & & 2 & $(2.9)$ \\
Petechial hemorrhage of skin & 1 & $(1.8)$ & & 0 & $(0.0)$ \\
Heart murmur & 2 & $(3.6)$ & & 2 & $(2.9)$ \\
\hline
\end{tabular}

The number of subjects examined is 56 (29 men and 27 women) in the exposed group, and 69 (32 men and 37 women) in the non-exposed control group. There was no significant $(\mathrm{p}>0.10)$ difference in the prevalence between the exposed and non-exposed groups.

${ }^{a}$ Number of cases with an abnormal sign in the item studied.

the work in past 3 month period (Table 5). The CNS-depressing effects of this chlorinated solvent after acute intensive exposure has been well documented. ${ }^{17-19)}$

The observation is in a general agreement with the findings in the previous studies from this study group. ${ }^{15,16,20,21)}$ For example, dizziness and headache were among the most common symptoms in those exposed to benzene or toluene, ${ }^{15}$ ) and the symptoms very similar to the present findings were common among the workers exposed to toluene. ${ }^{20,21)}$ Of particular interest is the fact that the workers exposed to trichloroethylene, a TETRA congener, had almost identical complaints. ${ }^{16)}$ In addition to such CNS effects, rough skin and frequent cough are typical local effects of TETRA (Table 5). In literature, Chmielewski et al. $^{22)}$ also described in their study on TETRA-exposed Polish workers that drawsiness, fatigue, headache and dizziness are among the most frequently complained CNS-related symptoms and that coughing and irritation in throat are also common among the workers of 1 to 10-year service history.

Whereas the present negative findings in hematology is in a good agreement 
with the general opinion that TETRA at occupational dose is not toxic to the hematopoietic system, ${ }^{23}$ possible hepato-renal toxicity of this compound may deserve discussion. The early observation by Franke and Eggeling ${ }^{24)}$ and the recent findings by Gluszczowa ${ }^{25}$ are in a close agreement with each other in that the effects of the occupational exposure to TETRA in dry-cleaning facilities to elevate ASAT and ALAT in serum is very minute, if present. In the cases of accidental high-dose exposure to TETRA, most authors observed no ${ }^{26}$ ) or minimal and transient effect ${ }^{27,28)}$ on the liver. In a statistical review of cases, McCarthy and Jones ${ }^{29)}$ also reported that the involvement of the liver is rather rare in the industrial gassing cases. In contrast, Meckler and Phelps ${ }^{30)}$ described a case of woman who was heavily exposed to TETRA during cleaning and maintenance work of dry-cleaning machines and subsequently showed liver enlargement, jaundice and remarkable increases in serum ASAT. The liver biopsy, made immediately before discharge from the hospital in 2 months, disclosed significant changes in the histology. The present negative observation on liver function (Table 6) is in the support of the observation by Franke and Eggeling ${ }^{24)}$ and Gluszczowa. ${ }^{25}$ ) Effect on kidney in the present study was also negative as judged by BUN and creatinine in serum (Table 6). No serious attention was paid on kidney function changes in the above-cited accidental cases, ${ }^{26,28,30}$ ) except that Saland ${ }^{27}$ ) observed one case each of transient microscopic hematuria and albuminuria among 9 firemen after heavy TETRA exposure during the fight against fire in a cellar. Although subtle changes might occur in kidney function after occupational TETRA exposure, ${ }^{31)}$ it appears likely that the kidney involvement may not be very severe in occupational circumstances.

\section{ACKNOWLEDGMENT}

The authors are grateful to Prof. T. Suzuki, the Director of Tohoku Rosai Hospital, Sendai 980, Japan, for his interest in and support to this work.

\section{REFERENCES}

1) International Agency for Research on Cancer. Tetrachloroethylene. IARC Monogr Eval Carcinog Risks Hum 1987; Suppl. 7:355-7.

2) Kyyrönen P, Taskinen H, Lindbohm M-L, Hemminki K, Heinonen OP. Spontaneous absorptions and congenital malformations among women exposed to tetrachloroethylene in dry cleaning. J Epidem Commun Health 1989; $43: 346-51$.

3) Environment Agency, the Government of Japan. Note on Ground Water Pollution. Water Quality Bureau, Environment Agency, Tokyo. (In Japanese)

4) Möse JR, Wilfinger G, Zeichen R. Trinkwasserverunreinigung durch Tetrachloräthylen. Zbl Bakt Hyg 1985; I Abt Orig B 181:111-20.

5) Coffin RR, Witherell LE, Novick LF, Stone KM. Establishment of an eyposure level to tetrachloroethylene in ambient air in Vermont. Public Health Reports 1987, 102:681-7.

6) Kido K, Shiratori T, Watanabe T, Nakatsuka H, Ohashi M, Ikeda M. Correlation of tetrachloroethylene in blood and in drinking water: A case of well water po!lution. Bull Environ 
Contam. Toxicol $1989 ; 43: 444-53$.

7) International Programme on Chemical Safety. Environmental Health Criteria 31 Tetrachloroethylene. World Health Organization, Geneva, 1984.

8) Seiji K, Inoue O, Jin C, Liu Y-T, Cai S-X, Ohashi M, Watanabe T, Nakatsuka H, Kawai T, Ikeda M. Dose-excretion relationship in tetrachloroethylene-exposed workers and the effect of tetrachloroethylene coexposure on trichloroethylene metabolism. Am J Ind Med 1990a; 16:675 $-84$.

9) Seiji K, Jin C, Watanabe T, Nakatsuka H, Ikeda M. Sister chromatid exchanges in peripheral lymphocytes of workers exposed to benzene, trichloroethylene, or tetrachloroetylene, with reference to smoking habits. Int Arch Occup Environ Health 1990b; 62:171-6.

10) Ikeda M, Hara I. Evaluation of the exposure to organic solvents by means of urinalysis for metabolites. Jpn J Ind Health 1980; 22:3-17. (In Japanese with an English abstract)

11) Ikeda M, Imamura T. Biological half-life of trichloroethylene and tetrachloroethylene in human subjects. Int Arch Arbeitsmed 1973; 31:209-24.

12) Hirayama T, Ikeda M. Applicability of carbon felt to the dosimetry of solvent vapor mixture. Am Ind Health ass J 1979; 40:1091-6.

13) Ikeda M, Kumai M, Aksoy M. Application of carbon felt dosimetry to field studies distant from analytical laboratory. Ind Health $1984 ; 22: 53-8$.

14) Inoue T. A table for subjective symptom questionnaires for solvent workers. In: Japan Industrial Safety and Health Association, eds. Health Management of Solvent Workers. Tokyo; Japan Industrial Safety and Health Association, 1983:66-7 (In Japanese).

15) Yin S-N, Li G-L, Hu Y-T, Zhang X-M, Jin C, Inoue O, Seiji K, Kasahara M, Nakatsuka H, Ikeda M. Symptoms and signs of workers exposed to benzene, toluene or the combination. Ind Health $1987 ; 28: 113-30$.

16) Liu Y-T, Jin C, Chen Z, Cai S-X, Yin S-N, Li G-L, Watanabe T, Nakatsuka H, Seiji K, Inoue $\mathrm{O}$, Kawai $\mathrm{T}$, Ukai $\mathrm{H}$, Ikeda $\mathrm{M}$. Increased subjective symptom prevalence among workers exposed to trichloroethylene at sub-OEL levels. Tohoku J Exp Med 1988; 155:183-95.

17) Steward RD, Erley DS, Schaffer AW, Gay HH. Accidental vapor exposure to anaesthetic concentrations of a solvent containing tetrachloroethylene. Ind Med Surg 1961; 30:327-30.

18) Patel R, Janakiraman N, Towne WD. Pulmonary edema due to tetrachloroethylene. Environ Health Perspect 1977; $21: 247-9$.

19) Levine B, Fierro MF, Goza SW, Valentour JC. A tetrachloroethylene fatality. J Foren Sc 1981; $26: 206^{-9}$.

20) Lee B-K, Lee S-H, Lee K-M, Cho K-S, Ahn K-D, Kim S-B, Ukai H, Nakatsuka H, Watanabe T, Ikeda M. Dose-dependent increase in subjective symptom prevalence among toluene-exposed workers. Ind Health $1988 ; 26: 11-23$.

21) Ikedas M, Watanabe T, Nakatsuka H, Takeuchi Y, Uchida Y, Iwami O, Liu S-J, Jin C, Cai S-X, Yao Y-M. Exposure-effect and exposure-excretion relationship among toluene-exposed workers. Abstract p. 7-8, presented at the International Symposium on Toxicology, held in Beijing, China, on 16-19th October, 1990.

22) Chemielewski J, Tomaszewski R, Glombioski P, Kowalewski W, Kwiatkowski SR, Szczekocki W, Winnicka A. Clinical observations of the occupational exposure to tetrachloroethylene. Biul Inst Med Morskiej 1976; $27: 197-205$.

23) Torkelson TR, Rowe VK. Tetrachloroethylene. In : GD Clayton and FE Clayton (eds) Patty's Industrial Hygiene and Toxicology 3rd revised edition Vol. 2B, Wiley-Interscience, New York. pp. $3560-8$.

24) Franke W, Eggeling F. Klinisch-statistische Untersuchungen bei perchloräthylen-exponierten Beschaftigten in Chemisch-Reiniger-Betrieben. Med Welt 1969; 9:453-60. (In German)

25) Gluszczowa M. Evaluation of the state of health of chemical laundries workers exposed to perchloroethylene (PER). Med Pracy 1988; 3:200-5. (In Polish with an English summary)

26) Ueda Y, Saito T, Ohwaki Y, Isonishi H, Fushiya Y. Chemical pneumonia due to tetrachloroethylene aspiration. Nippon Rinsho 1966; $24: 1185-8$. (In Japanese)

27) Saland G. Accidental exposure to perchloroethylene. NY State J Med 1967; 67:2359-61.

28) Stewart RD. Acute tetrachloroethylene intoxication. J Am Med Ass 1969; $208: 1490-2$. 
29) McCarthy TB, Jones RD. Industrial gassing poisonings due to trichloroethylene, perchloroethylene, and 1-1-1 trichloroethane, 1961-1980. Br J Ind Med 1983; 40:450-5.

30) Meckler LC, Phelps DK. Liver disease secondary to tetrachloroethylene exposure. J Am Med Ass 1966; $197: 144-5$.

31) Mutti A, Biagini C, Giovanetti M, Franchini I, Roels H, Bernard A, Lauwerys R. Cross-sectional investigation of early renal disturbances in workers occupationally exposed to tetrachloroethylene (PERC). Abstract p. 281, presented at the International Congress on Industrial Health, held in Montreal on 22-28th September, 1990. 